\title{
Comparative Analysis of Taiwan Fire Risk with Asia/Oceania and Other Countries around the World
}

\author{
WEI-WEN TSENG, SHEN-WEN CHIEN, and TZU-SHENG SHEN \\ Fire Science Department, \\ Central Police University \\ No. 56, Shujen Rd., Takang Village, Kueishan Hsiang, \\ Taoyuan County, 33304, Taiwan
}

\begin{abstract}
This paper addresses the problem of societal fire risk perception by using the Taiwanese fire statistics, description of fire risk in Asia/Oceania countries, and comparison with levels of fire risk in Australia, Japan, the UK and USA. It is demonstrated that the fire statistics in Taiwan indicates a progress in fire safety provisions, underlying the importance of fire service reorganization since 1995. Some countermeasures, including such as "Community Woman Fire Safety Advisors" and "Fire Safety Feng Shui Masters", proposed by a new central and local fire authorities contributed significantly to the progress. Performed analysis of fire statistics through countries of Asia/Oceania region illustrates that each country has its own problems, which likely depend on climate, natural and built environment, and economy. Through comparison with fire risk problems in leading world countries, paper identifies and explores some important issues of fire safety in Taiwan, e.g. the need to develop in Taiwan a unified fire incident/accident data base system involving local fire brigades.
\end{abstract}

KEYWORDS: statistics, fire risk, Asia/Oceania countries

\section{INTRODUCTION}

This paper hopes to address the perception of societal fire risk by using the limited available Taiwanese fire statistics, then generally to explore the quantification of fire risk in other Asian countries, and finally to make an international comparison with Australia, Japan, the U.K. and the U.S.A. which are considered to have more comprehensive and easily accessed fire data.

The Taiwanese fire statistics in this paper are derived from a website, released officially by its National Fire Agency (NFA), Ministry of the Interior. For Asian fire analysis, the statistics are based on a collection of the data published by the International Fire Chiefs' Association of Asia (IFCAA) for its members. For international comparison, the section tries to find the characteristics of fire risk, especially from the viewpoint of loss of life risk and fire occurrences, through comparison with the published statistics of Australia, Japan, the U.K. and the U.S.A. The statistics are mainly obtained from "World fire statistics" [1] published by the International Association of Fire and Rescue Services (CTIF). Other resources on the website entitled "Fire Statistics - United Kingdom" and "Fire Statistics - U.S. Fire Administration" are used to reexamine the related information. Taiwan statistics are also added to regional analysis and international comparison for the purpose of providing further references for the Taiwan fire authority.

\section{FIRE RISK IN TAIWAN}

Taiwan is an island country with a total area of 35,563 square kilometers (13,731 square miles approximate). The population of 23 millions is distributed mainly in a plane area along the west coast, especially in the northern part of Taiwan. Because Taiwan is located in the pacific-rim seismic area and tropical cyclone zone, the government and people are well accustomed to the threats of natural disasters such as typhoons, earthquakes and floods.

Taiwan's prosperous economy has encouraged people to migrate from rural areas to the cities. To satisfy the requirement for high-density accommodation in the limited space of urban areas, high-rise structures are commonplace. A lot of composite buildings containing combinations of domestic, commercial, 
institutional, hotel or public assembly occupancies are a typical feature of the building stock in metropolitan areas.

The people of Taiwan like a boisterous and convenient daily life. One appearance that most Seven-Elevens (24 hours convenient store) and traditional snack stands are run in the ground floor of residential apartments and buildings in prosperous urban areas. Nightlife is also very varied. Karaoke, KTV (Karaoke in private lounges), MTV (Movie in private lounges), leisure barbershops, saunas, pubs, nightclubs and 24-hour cinemas attract different classes of consumers. Although the implementation and execution of the By-law of Zoning Management in Metropolitan Areas limits the business district, it is difficult to avoid the invasion of business activities and improve the living quality in the residential areas due to the rapid development of the economy.

\section{Characteristics of Fire Risk}

Each year fires kill hundreds of people and destroy billions of dollars of worth property in Taiwan. However, many problems causing far less casualty risk than fires, such as floods and typhoons as shown in Table 1, receive much more attention and have much greater resources devoted to the mitigation of their effects. The reason is that natural disasters mainly occur in certain periods of time and usually cause serious loss of life and damage in each accident and are thus perceived as catastrophic events. Such situation also responses to Wolski's explanation [2] to risk perceptions. In contrast with natural disasters, fire incidents occur virtually everyday and cause loss of life and damage to varying degrees. Unlike advanced countries such as the United Kingdom, the reporting and recording system is not well developed in Taiwan. All fire data are taken from reports of fires provided by local fire brigades. When the fire authorities wish to pursue a fire safety program they require the cooperation of other people or bodies, it is quite important to impress the fire risk perceptions and to attract social attention on the specific fire safety problem with reliable fire statistics. Therefore, how to collect and use data to illustrate fire problems and go one step further and initiate proper programs is the challenge for fire authorities in Taiwan.

Table 1 shows that fire deaths are getting lower year by year, especially after 1995 when the NFA was established. Deaths in fire incidents have decreased since 1995 from 10,916 incidents with a death toll of 294 people to 18,254 incidents with a death toll of 230 in 1999, and to 5,139 incidents claiming 139 lives in 2005. Further improvements have seen the agency set the lowest record since its establishment, with fire incidents dropping to 4,332 with a death toll of 125 lives in 2006. Some countermeasures proposed and executed by the NFA and local fire authorities respectively seem to have been effective, such as promoting fire safety equipment inspection and declaration, popularizing flame retardant decorations, establishing a fire safety equipment approval system, and strengthening fire safety management in public occupancies. However, it deserves to mention the inconsistency of local fire data collection systems in Taiwan is usually denounced by fire safety communities, which is also believed the main reason to the dramatic decline in fires from 2002 to 2006.

In addition, it is worth mentioning some effective countermeasures that reduce residential fires, which remain approximately over $60 \%$ of total fires and cause the majority of deaths in many countries. Two specific countermeasures that have reduced residential fires noticeably are: "Community Woman Fire Safety Advisors" and "Fire Safety Fen Shui Masters", promoted by central and local fire authorities respectively.

The advantage of the community women volunteers is that they are familiar with their communities and find it easier to go from apartment to apartment without causing privacy and security issues for the inhabitants. In addition, Feng Shui is an ancient art and science developed over 3,000 years ago in Chinese society. It is a complex body of knowledge that reveals the ways to balance the energies of the environment to assure health, wealth and good fortune for the people inhabiting it. Applying this concept to fire safety, the volunteer masters evaluate residential fire safety, indicate fire risk, and offer some suggestions for Taipei citizens. Whether woman advisor or Fen Shui Master, they are well trained in certain major tasks, including promoting increased fire prevention awareness, advocating residential fire safety analysis measures, strengthening electrical usage guidance, planning escape routes, promoting the installation of home smoke alarm detectors, and building up high risk profile information on the potential dangers in old 
communities or private accommodations which fire authorities are difficult to step in officially. The specific achievements of Community Women Safety Advisor and Fire Safety Fen Shui Masters are demonstrated in Chien's work. [3]

Table 1. Fires and natural disasters caused casualty damage in Taiwan (1993 2006)

\begin{tabular}{|c|c|c|c|c|c|c|c|c|}
\hline Incident & year & 1993 & 1994 & 1995 & 1996 & 1997 & 1998 & 1999 \\
\hline \multirow{3}{*}{ Fires } & No. & 9870 & 10763 & 10916 & 13309 & 15115 & 14555 & 18254 \\
\hline & Deaths & 377 & 330 & 294 & 275 & 226 & 306 & 230 \\
\hline & Injuries & 706 & 696 & 614 & 782 & 633 & 763 & 649 \\
\hline \multirow{3}{*}{$\begin{array}{c}\text { Natural } \\
\text { Disasters }\end{array}$} & No. & 5 & 9 & 6 & 5 & 7 & 7 & 4 \\
\hline & Deaths & 4 & 91 & 34 & 76 & 74 & 58 & $2465^{2}$ \\
\hline & Injuries & 6 & 178 & 30 & 463 & 127 & 59 & $10982^{2}$ \\
\hline \multirow[t]{2}{*}{ Incident } & year & 2000 & 2001 & 2002 & 2003 & 2004 & 2005 & 2006 \\
\hline & No. & 15560 & 13750 & 13226 & $8642^{3}$ & 6611 & 5139 & 4332 \\
\hline \multirow[t]{2}{*}{ Fires } & Deaths & 262 & 234 & 193 & 228 & 160 & 139 & 125 \\
\hline & Injuries & 732 & 807 & 671 & 692 & 652 & 532 & 471 \\
\hline \multirow{3}{*}{$\begin{array}{c}\text { Natural } \\
\text { Disasters }\end{array}$} & No. & 10 & 9 & 4 & 8 & 10 & 6 & 9 \\
\hline & Deaths & 117 & 235 & 11 & 7 & 93 & 49 & 13 \\
\hline & Injuries & 225 & 578 & 281 & 20 & 536 & 153 & 87 \\
\hline \multicolumn{9}{|c|}{ 1. Natural disasters include torrential rain, flood, and earthquake. } \\
\hline 2. The de & stating Chi-C & arthquake & sed $2456 \mathrm{c}$ & & 8 iniur & ntemb & 9. & \\
\hline \multicolumn{9}{|l|}{ 3. The ne } \\
\hline
\end{tabular}

\section{Causes of fires}

As Fig. 1 shows various causes of fires from 2003 to 2006, the top five fire causes in order are:, electricity, smoking, arson, machinery (e.g. overheated bearing), and cooking. Unknown fire cause still takes a high percentage that needs more efforts to improve investigation techniques for fire authorities. It is clear that about $48 \%$ of the total is caused by electricity, smoking, and arson. In Taiwan, an example of an electricity fire is a fire caused by overheated wires in electronically powered equipment, i.e. it refers to any fire from any cause involving electrically powered equipment. According to fire investigations conducted the NFA, by overheated wires or short circuits cause most of the electricity fires. Improperly using fire in daily life relates to human behaviour, i.e. mainly human error and disregarding safety rules. Another major fire cause, which should be noted, is smoking, which ranked in third position at $13 \%$. According to a recent investigation by the Department of Health, Executive Yuan, the smoking population is increasing to 4.5 millions by around $20 \%$ total population and the age level is decreasing, year after year, as western cigarette manufacturers invade the Taiwan market. Fire authorities attribute the large smoking population to cheap cigarettes (less than £1 per pack in Taiwan). It is clear that the primary fire causes from cigarettes cannot be avoided in the future.

\section{Arson problems}

Arson is the deliberate setting of fires to destroy property or even murder people, and is a rising problem in modern Taiwan society. This is shown in Fig. 1, with a high ratio of around 9.5\% confirmed arson and $24.9 \%$ unknown (including some of suspicious arson) of total fire incidents maintained during past few years. Fire is used as a crime tool because it is easy to use and burning and fire fighting can destroy a crime scene. This is a serious problem in Taiwan, as shown in Table 2. Many significant fires, causing serious life losses are related to arson.

Premises running special business such as KTV, Karaoke, Pub, and massage barbershops are maliciously attacked by drunk arsonists that serious casualties as shown in Table 2. Fortunately there is no significant fire that has caused over 10 deaths since 1997 that has involved arson. Actually, some countermeasures of 
arson prevention proposed by the NFA have been effective, such as a ban on parking motorcycles in front of the main door of some special business and training in fire extinguishing for security staff. From the table 2 it can be seen that arson is a more probable cause in high death number fires than in ordinary fires because malicious arsonists always set fires with some unexpected ways which lose control easily such as igniting the oil pipes of scooters or small LPG tanks. According to the ratio of confirm arson for past few years, the potential hazards are still rising continuously and to the highest $11 \%$ of total fires in 2006 . As a result, the importance of fire safety design grows dramatically. It is clear that traditional fire prevention measures are not effective against arson. Fire authorities should propose more fire protection countermeasures for arson problems in Taiwan.

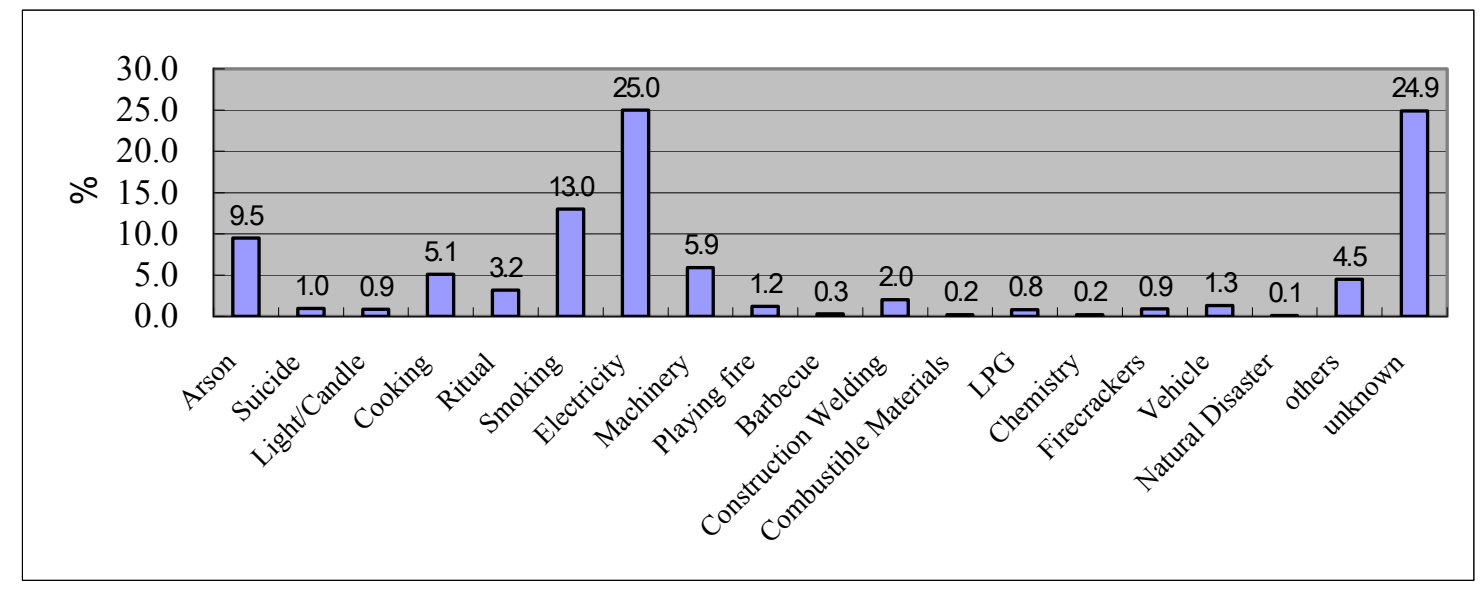

Fig. 1. Causes of total fires in Taiwan (2003 - 2006)

Table 2: Significant fires in Taiwan (1992 -1996)

\begin{tabular}{|c|l|c|c|c|}
\hline Date & Incident Occupancies & Deaths & Injuries & Causes \\
\hline $11 / 05 / 1992$ & Taipei County Bowling Alley & 20 & 0 & Tinder \\
\hline $23 / 09 / 1992$ & Tonight Karaoke & 13 & 3 & Cooking \\
\hline $20 / 10 / 1992$ & Kaohsiung Hua-Ji Hotel & 17 & 15 & Electricity \\
\hline $21 / 11 / 1992$ & Taipei City Legend World KTV & 16 & 2 & Arson \\
\hline $19 / 01 / 1993$ & Taipei City Restaurant & 33 & 21 & Arson \\
\hline $10 / 04 / 1993$ & Karaoke & 10 & 4 & Arson \\
\hline $12 / 05 / 1993$ & Barber Shop & 21 & 8 & Arson \\
\hline $25 / 10 / 1994$ & KTV & 13 & 1 & Electricity \\
\hline $15 / 02 / 1995$ & Welcome Restaurant & 64 & 16 & Cooking \\
\hline $17 / 04 / 1995$ & KTV & 11 & 13 & Arson \\
\hline $31 / 10 / 1995$ & Building & 11 & 8 & Smoking \\
\hline $18 / 02 / 1996$ & Sauna & 17 & 0 & Electricity \\
\hline $27 / 02 / 1996$ & Building & 13 & 17 & Arson \\
\hline
\end{tabular}

* So far, there is no significant fire that caused over 10 deaths from 1997.

\section{AN OVERVIEW OF ASIA/OCEANIA FIRE STATISTICS}

Table 3 shows the latest statistics from the IFCAA's publication. The organization was established on the strong request of fire chiefs in Asian countries in 1958. The purpose of this Association is to maintain international friendly relations among fire chiefs in Asian countries, to promote the study of techniques and measures for fire safety, to exchange fire service knowledge / information, and thus to contribute to the development of Asia's fire services. The association is planning to issue fire statistics periodically to help 
its members better understand the fire service in Asian and Oceania countries. Some fire risk and fire service issues are discussed as follows:

Table 3. Statistics of fire service in Asia and Oceania countries (2002-2005)

\begin{tabular}{|c|c|c|c|c|c|c|c|c|}
\hline Country & 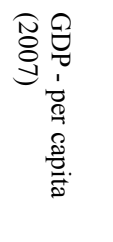 & 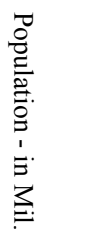 & 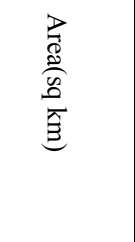 & 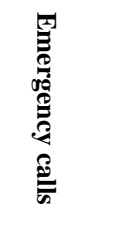 & 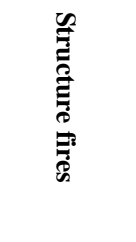 & 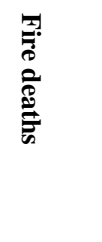 & 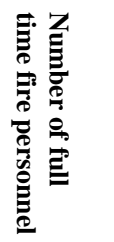 & 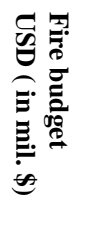 \\
\hline [Australia] & $\$ 42,553$ & {$[1.5]$} & - & - & [1256] & [7] & [793] & [65.5] \\
\hline Bahrain & $\$ 22,109$ & 0.7 & 665 & 8,176 & 900 & 8.75 & 588 & - \\
\hline Bangladesh & $\$ 444$ & 141 & 144,000 & 17,266 & - & 67.8 & 4497 & 18.5 \\
\hline Brunei & $\$ 32,501$ & 0.4 & 5,770 & 2,661 & 99 & 1.2 & 1117 & 18.386 \\
\hline $\begin{array}{l}\text { Hong Kong } \\
\text { [India] }\end{array}$ & $\begin{array}{r}\$ 29,149 \\
\$ 965\end{array}$ & $\begin{array}{r}7 \\
{[14]}\end{array}$ & $\begin{array}{r}1,092 \\
{[1483]}\end{array}$ & $\begin{array}{l}622,069 \\
{[15275]}\end{array}$ & $\begin{array}{r}5165.8 \\
{[6396.5]}\end{array}$ & $\begin{array}{r}17.6 \\
{[116.5]}\end{array}$ & $\begin{array}{r}8588 \\
{[2266]}\end{array}$ & $\begin{array}{r}391.2 \\
{[117.5]}\end{array}$ \\
\hline [Indonesia] & $\$ 1,824$ & [806] & {$[661]$} & [822] & [060] & [27] & [2865] & [25.5] \\
\hline [Iran] & $\$ 3,920$ & [11.1] & [864] & [115200] & [2290] & [104] & [2188] & [57.5] \\
\hline Israel & $\$ 22,073$ & 6.8 & 20,770 & 85,692 & 4869.2 & 19.25 & 1550 & 50.6 \\
\hline Japan & $\$ 34,023$ & 127.5 & 377,835 & - & 32916 & 2147.4 & 155573 & 110 \\
\hline Korea & $\$ 19,624$ & 48.4 & 98,480 & $1,239,168$ & 16674 & 534 & 27768 & 16791.8 \\
\hline $\begin{array}{l}\text { Kuwait } \\
\text { Malaysia }\end{array}$ & $\begin{array}{r}\$ 32,259 \\
\$ 6,146\end{array}$ & $\begin{array}{r}2.6 \\
26.4\end{array}$ & $\begin{array}{r}17,820 \\
329,753\end{array}$ & $\begin{array}{r}10,415 \\
41,648\end{array}$ & $\begin{array}{l}1978.4 \\
3582.2\end{array}$ & $\begin{array}{l}10.6 \\
70.4\end{array}$ & $\begin{array}{r}1956 \\
10250\end{array}$ & $\begin{array}{r}1581.8 \\
136.8\end{array}$ \\
\hline Mongolia & $\$ 1,470$ & 2.5 & $1,564,116$ & 2,262 & 644.6 & 52.4 & 2342 & 191 \\
\hline $\begin{array}{l}\text { New Zealand } \\
\text { Papua New Guinea }\end{array}$ & $\begin{array}{r}\$ 29,698 \\
\$ 997\end{array}$ & $\begin{array}{r}4 \\
5.2\end{array}$ & $\begin{array}{l}268,680 \\
462,842\end{array}$ & $\begin{array}{r}66,786 \\
287\end{array}$ & $\begin{array}{r}6498.8 \\
187.4\end{array}$ & $\begin{array}{r}33.4 \\
3.8\end{array}$ & $\begin{array}{r}1607 \\
391\end{array}$ & $\begin{array}{l}147.6 \\
2.094\end{array}$ \\
\hline Philippines & $\$ 1,590$ & 87 & 305,083 & 23,308 & 5012.2 & 257 & 14483 & 65.6 \\
\hline Singapore & $\$ 34,152$ & 4.4 & 693 & 92,064 & 3768.4 & 2.4 & 1431 & 188.2 \\
\hline [Syria] & $\$ 1,928$ & [4] & {$[1600]$} & [2830] & [423] & [67] & [670] & {$[2.6]$} \\
\hline Taiwan & $\$ 16,274$ & 22.8 & 35,980 & 664,020 & 3478.4 & 167.8 & 9257 & 610.4 \\
\hline
\end{tabular}

* The contents in brackets show the statistics in the capital area.

* Data from IFCAA Fire Statistics

\section{Emergency calls}

There are various emergency calls from inhabitants in each country. Excluding fire, other incidents include road traffic accidents, people trapped in machinery or trapped down shafts or at heights, petrol and chemical spills, animals trapped, and even body recovery are usefully passed to fire services for emergency response actions. The utility rate of emergency calls shown in Fig. 2 in each Asian country are highly related to its GDP per capita as shown in Table 3, which may be explained by its telecom infrastructure development.

Unlike western countries, fire services in Asian countries like Hong Kong, Japan, Taiwan, Korea and Singapore should take charge of the professional work in the field of Emergency Medical Service (EMS). As shown in Fig. 2, over 90\% emergency calls are for EMS. Even with such a heavy burden for fire services, the authorities still continue to put more effort into advancing their EMS systems because such services are the best way to increase the profile of fire authorities. For example, the National Fire Agency in Taiwan is fully engaged in implementing an emergency medical service system and building a guardian network, which safeguards lives nationwide. Up to 2006, there were 8,378 fire-fighters qualified as emergency medical technicians (EMT), accounting for $88 \%$ of fire-fighters nationwide. With the addition of these emergency medical experts, the number of emergency medical service staff has been growing at an average of $10 \%$ every year. The number of emergency medical service staff on duty was 678,987 in 2005 , and 692,607 in 2006. An average of 1,898 emergency service staffs was on duty daily with total 9,257 fire 
personnel in Taiwan. The number of people served was 529,320 in 2005, rising to 537,943 in 2006 with an average of 1,474 people serviced daily. This performance produced the highest public service satisfaction record in Taiwan. By contrast, some countries such as UK, USA and New Zealand that does not deal with EMS issues may put all their efforts in the area of fire safety.

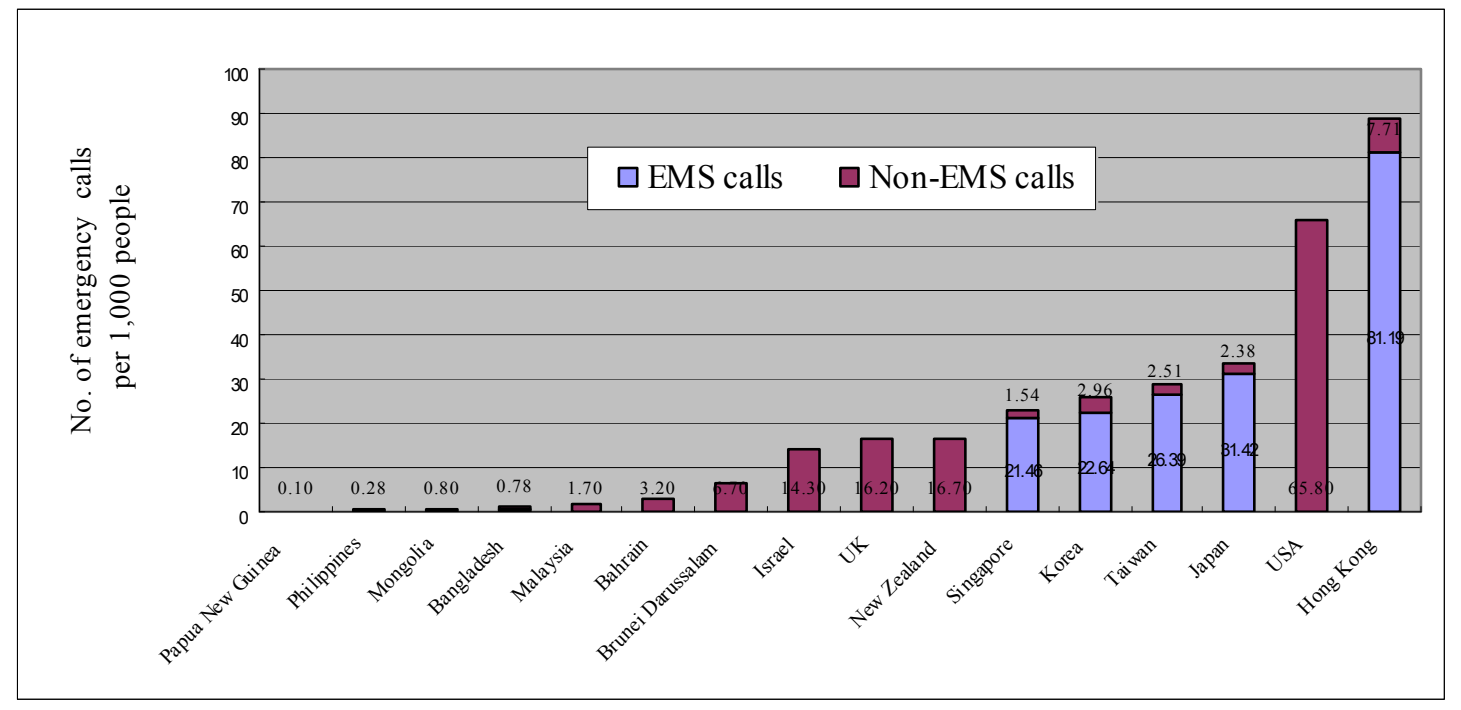

Fig. 2. Average of emergency call a year per 1000 person

\section{Fire Causes}

As shown in table 4, there are 15 Asian and Oceania countries with electrical problems in their top five fire causes. It is difficult to place a common nomenclature into each fire cause because of different way of life in each country. Regardless of what terminologies they use including: short circuit, equipment failure, electrical leakage, or just electricity. Furthermore, it can be anticipated that the use of general electricity will continue to increase along with economic development. Based on this situation, it is necessary to apply safer design and use of wire distribution and electrical appliances. Meanwhile, the routine inspection of wire and appliance should be promoted. In addition, Arson problems also plague Asian and Oceania countries. Many unknown fire causes are also thought to involve arson. A number of these incidents were serious structural arson fires. However, in these developing countries, based on other advanced countries' experiences, the biggest problems will likely be deliberately setting fire to rubbish, out door fires and deliberate burning of parked vehicles or motorcycles. It deserves to find effective solutions as earlier as possible for fire authorities in those developing countries including Taiwan.

\section{Structure fires and deaths}

With the growth in fire safety engineering (FSE), as a discipline of performance-based design comes the need for more structure fire data, some of it in the form of statistics. For example, the FSE approach requires definitions of fire scenarios, and likelihood of various structure fires for risk assessment purposes. The numbers of structure fires in Asia and Oceania countries are shown in Fig. 3. UK and USA data also are listed for relative comparison. We can find that the structure fires in most Asian and Oceania countries like Taiwan, Malaysia, and the Philippines are significantly lower than western countries like the UK and the USA. We can conclude that the main reason for this is that the numbers are under estimated due to no specific data collection systems in those Asian countries. Another reason may be the type of architecture of residential buildings. Residential building fires accounted for over $60 \%$ of all structure fires. Such relatively frequent occurrences of fires are also observed in fire incident statistics in the UK, Australia, U.S.A. and Japan. [4] 
Figure 4 shows fire death rates per million people in 15 Asia countries from 2002 to 2006. The USA and UK statistics from 1996 to 2002 for reference are listed for related comparison. The events of September 11, 2001 (2,451 civilian and 340 firefighter deaths) dramatically increase the U.S.death rate should be noticed. Except Bahrain, which had serious loss of life in 2006 of 22 deaths with a population only 700,000 people, countries located in higher latitudes tend to suffer higher fire death rates. This may indicate the role of alcohol and failure of heating sources in the higher death rates in those countries. This might also be the case in Eastern Europe countries.

Table 4. Top 5 of fire causes in Asia/Oceania Countries in 2005-2006

\begin{tabular}{|c|c|c|c|c|c|}
\hline Countries & $1 \mathrm{st}$ & 2nd & 3 rd & 4th & 5 th \\
\hline [Australia] & Incendiary & Suspicious & $\begin{array}{l}\text { Abandoned } \\
\text { Materials }\end{array}$ & Overloaded & $\begin{array}{l}\text { Electrical } \\
\text { Failure }\end{array}$ \\
\hline Bahrain & Short Circuit & Unknown & Carelessness & Deliberately & Cigarettes \\
\hline Bangladesh & Short Circuit & Oven & Cigarette & Unknown & Open Lamp \\
\hline Brunei & Electricity & Gas \& Other & Arson & Playing Fire & Bon Fire \\
\hline Hong Kong & Smoking & Cooking & Electricity & Undetermined & Miscellaneous \\
\hline [Indonesia] & Electric Leakage & Others & Kerosene Stove & Cigarette & Lamp \\
\hline [Iran] & Arson & Short Circuit & Burning Rubbish & Unknown & Expose to heat \\
\hline Israel & Electricity & Smoking & Arson & Playing Fire & - \\
\hline Japan & $\begin{array}{c}\text { Arson \& } \\
\text { Suspicious }\end{array}$ & Cooking Stove & Smoking & Bonfire & Stove \\
\hline Korea & Electricity & Arson & Cigarette & Sparks & Playing Fire \\
\hline Kuwait & Short Circuit & Playing Fire & Cigarette & Overload & Arson/Suspicious \\
\hline Malaysia & Electricity & Unknown & Others & $\begin{array}{l}\text { Gas/Kerosene } \\
\text { Stove }\end{array}$ & $\begin{array}{l}\text { Mosquito Coils, } \\
\text { Candle, Joss Stick }\end{array}$ \\
\hline Mongolia & Electricity & Open Fire & Stove & Cigarette, Match & Playing Fire \\
\hline New Zealand & Unlawful & Deliberate & $\begin{array}{l}\text { Equipment } \\
\text { Failure }\end{array}$ & $\begin{array}{c}\text { Careless Disposal } \\
\text { Cigarette }\end{array}$ & Cooking \\
\hline $\begin{array}{c}\text { Papua New } \\
\text { Guinea }\end{array}$ & Electricity & Arson & Unknown & Carelessness & Candle \\
\hline Philippines & Electricity & Combustion/Flames & Unknown & Others & Cigarette \\
\hline Singapore & $\begin{array}{c}\text { Light Thrown } \\
\text { Down }\end{array}$ & Food overheating & Electrical & Incendiary & Naked Light \\
\hline [Syria] & Unknown & Negligence & Purposely & False & - \\
\hline Taiwan & Electricity & Cigarette & Arson & Machinery & Cooking \\
\hline
\end{tabular}

To summarize, the number of structure fires and fire deaths, and their rates per population, among countries, with smaller populations, like New Zealand, Bahrain, Kuwait, and Singapore, appear to be much higher than other Asia countries for recent years. However, differences in fire incident rates per population depend greatly on differences in definitions or reporting systems for fire incidents, especially in small fires, which are usually extinguished by the occupants and are not reported to fire brigades.

By contrast, the number of reported fire deaths seems to be more reliable because the data collected from the reporting systems in different countries are not as subjective. Before coming to compare Taiwan with other countries on the risk of loss of life, however, one important point must be clarified. The significant difference in the data used in each country does not give a uniform baseline. A common example is the accumulation of deaths in fire accidents. For example the UK counts all deaths caused by a fire where death by fire related causes is specified on the death certificate up to 3 months after the fire incident, however, the fire brigades in Taiwan count only those dying within 24 hours of the fire occurring. 


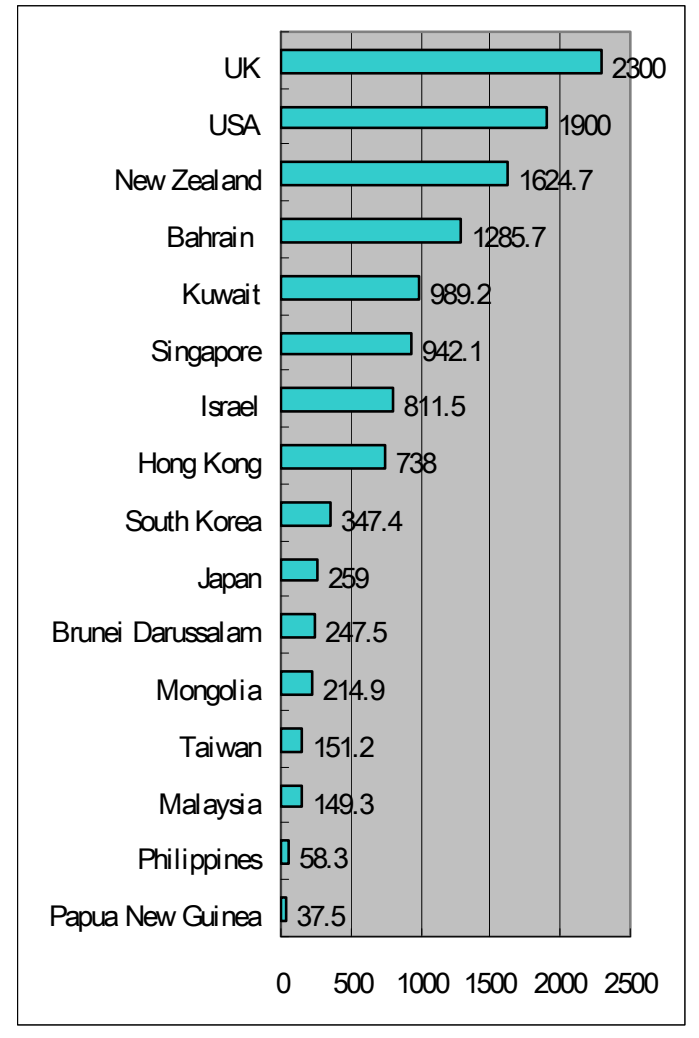

Fig. 3. Average of structure fires a year per Million

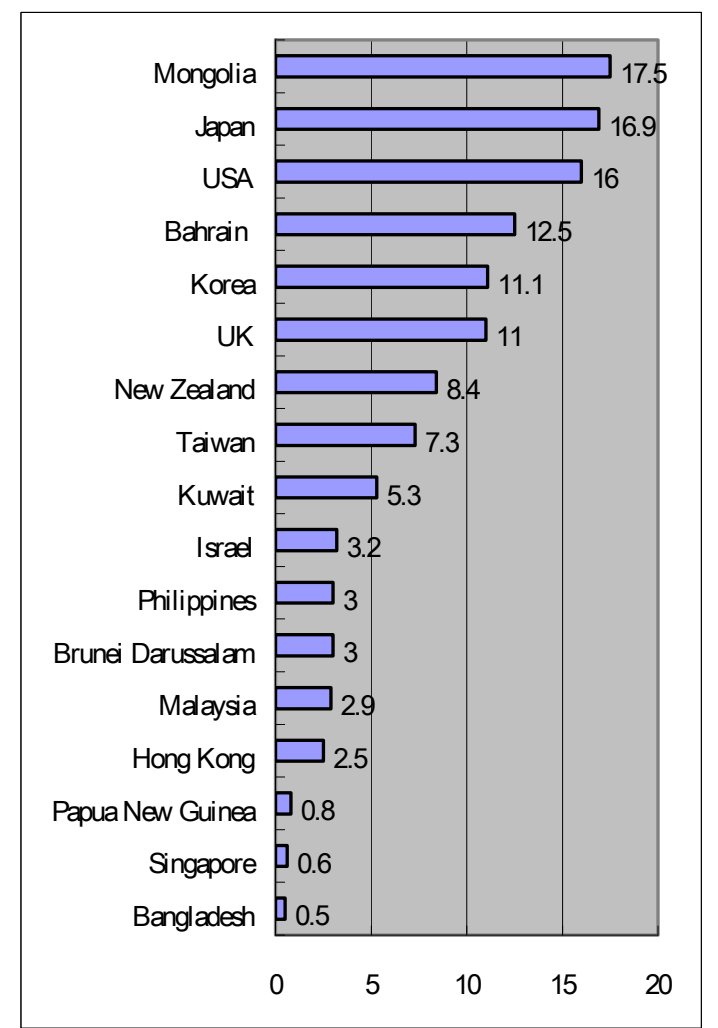

Fig. 4. Average of fire deaths a year per million

( Data from IFCAA Fire Statistics)

\section{COMPARISON BETWEEN AUSTRALIA, JAPAN, USA, THE UK AND TAIWAN}

As previously stated, there are a few countries, such as Australia, Japan, United Kingdom, and United States that have been collecting national fire statistics, publishing periodically, and releasing the data officially in English. Those reports are intended to illustrate fire losses, causes, fire patterns etc., to analyze the specific fire safety problems faced, to examine the effectiveness of proposed fire protection measures they have been promoting, and to learn lessons from past fires.

It is important to know that understanding statistical fire data not only includes recognizing risks, but also finding risk mitigation measures. By using Brushlinsky's approach [5], the evaluation of fire risks for people can be divided into three aspects. As shown in Table 5, the probability of a person facing a fire, death risk at a fire, and death risk for a person in a fire is expressed by total fires/population $\left(R_{1}=\Sigma F / \Sigma P\right)$, total deaths/total fires $\left(R_{2}=\Sigma D / \Sigma F\right)$, and total deaths/population $\left(R_{3}=\Sigma D / \Sigma P\right)$ respectively; i.e. $R_{3}=R_{1}$ $\mathrm{x} \mathrm{R}_{2}$.

To help understand the risk to life caused by fires, the information for loss of life risk for Australia, Japan, the United Kingdom, and the United States by using fire death rates per million people is shown in Table 5 . The U.S.A. and Japan have almost the same values by respective 16 and 17 fire deaths per million people, Taiwan has the lowest record with 7.3 fire deaths per million people which is an under estimation as mentioned in the previous section..

When comparing the possibility of people facing a fire in different countries, in Table 5, the UK and the USA have an almost approximate value of $11 \times 10^{-3}$ and $8 \times 10^{-3}$ respectively. Taiwan and Japan also have approximate values of $0.15 \times 10^{-3}$ and $0.5 \times 10^{-3}$. It can be concluded that this is due to the different cultural backgrounds, life styles, and environment in eastern and western countries. In this part, Taiwan also have 
underestimated value which cause the death risk at a fire $\left(\mathrm{R}_{2}\right)$ get much higher. It can be suspected that the number of fires is under reported or estimated in Taiwan to cause the higher death risks per fire.

To reduce the first aspect of fire risk, i.e. to reduce the occurrence of fires, the strategy should focus on fire prevention methods such as reducing ignition sources, reducing fuel, and limiting uses etc. However, to reduce the other two life risks, i.e. to reduce the deaths in fires, the strategy should emphasize fire protection and suppression methods including active and passive measures.

The challenge in reducing the above risks can be met through a series of fire safety options. For example, dealing with the risk of people facing a fire can be attained by decreasing fire occurrence through continuously educating people on common causes of fires, speed of fire spread and life-threatening fire scenarios. At the same time, buildings have to be designed which are safe for the occupants. This can be achieved by providing comprehensive means of escape and active/passive fire and life safety systems which can decrease fire deaths, i.e. these reduce the death risk of people facing a fire. The responsibility of providing fire safety options in buildings is borne mainly by the relevant legislators and administrators and is enforced via policing of regulations and technical guidance.

Table 5. Evaluation of Fire Risk for People by using Brushlinsky's approach [5]

\begin{tabular}{|c|c|c|c|}
\hline Country \& Risk & $\begin{array}{c}\text { Facing a Fire } \\
\text { [fires/people in millions] } \\
\mathrm{R}_{1}=\Sigma \mathrm{F} / \Sigma \mathrm{P}\end{array}$ & $\begin{array}{c}\text { Death Risk at a Fire } \\
\text { [fire deaths/fires] } \\
\mathrm{R}_{2}=\Sigma \mathrm{D} / \Sigma \mathrm{F}\end{array}$ & $\begin{array}{c}\text { Death Risk per Capita } \\
\text { [fire deaths/people] } \\
\mathrm{R}_{3}=\Sigma \mathrm{D} / \Sigma \mathrm{P}\end{array}$ \\
\hline Australia & $3.3 \times 10^{-3}$ & $0.3 \times 10^{-2}$ & $1.0 \times 10^{-5}$ \\
\hline Japan & $0.5 \times 10^{-3}$ & $3.4 \times 10^{-2}$ & $1.7 \times 10^{-5}$ \\
\hline Taiwan & $0.15 \times 10^{-3}$ & $4.9 \times 10^{-2}$ & $0.7 \times 10^{-5}$ \\
\hline United Kingdom & $11.0 \times 10^{-3}$ & $0.1 \times 10^{-2}$ & $1.1 \times 10^{-5}$ \\
\hline United States & $8.0 \times 10^{-3}$ & $0.2 \times 10^{-2}$ & $1.6 \times 10^{-5}$ \\
\hline
\end{tabular}

\section{CONCLUDING REMARKS}

The analysis of fire statistics in Taiwan shows that number of fires and fire deaths are significantly reducing on the annual basis. This achievement can be attributed to the countermeasures undertaken by the central and local fire authorities in the period 1995-2002 including implementation of "Community Woman Fire Safe Advisor" and "Fire Safety Feng Shui Masters" programmes. The current system of fire statistics, however, cannot represent in detail the whole spectrum of fire safety problems in Taiwan. More advanced system of reliable fire incident/accident data collection is needed. Indeed, unknown causes of fire origin, including suspicious arson, electrical faults and smoking, are the main reasons of fire Taiwan. It is concluded that arson is a serious problem requiring special attention already today for the Taiwanese fire authority.

The analysis of fire statistics in Asia and Oceania countries allowed to confirm that situation with fires is directly related to climate, environmental and economical issues. Both, number of building fires and fire deaths are higher in more developed countries. In all countries there is a tendency of increasing number of fires caused by electricity and arson. This issue should be addressed by the international fire research community and solutions have to be found.

Compared to Australia, Japan, United Kingdom, and United States, the most of fire safety measures in Taiwan used for fire prevention and fire safety management in buildings seem effective when analysing the possibility of fire risk for people facing a fire. However, the risk of fire death is still the most serious issue for people facing a fire. Any fire may have serious consequences and the key factor is performance-based fire safety design based on a firm knowledge. The analysis in this paper makes it clear that at the moment the attention paid by building owners, and even by fire and building authorities in Taiwan, to fire safety is not sufficient and erroneously based on the believe that the regulations provide completely adequate measures for fire protection in any situation. To tackle current problems more advanced system of fire statistics should be implemented in Taiwan in near future. This is a cross-border issue and further serious and continuous study is necessary [6]. International collaboration of fire authorities. through IFCAA and CTIF may seriously facilitate a move forward towards a better understanding of fire risk around the world and ways of its reduction. 


\section{REFERENCES}

[1] Brushlinsky, J.R., Hall J.R., Sokolov S.V., Wanger P., World Fire Statistics, Report No. 12 - 2nd Edition, International Association of Fire and Rescue Services, 2005

[2] Wolski A., Dembsey N. A., and Meacham B. J., Accommodating Perceptions of Risk in Performance-based Building Fire Safety Code, Fire Safety Journal 34, 2000, 297-309 doi:10.1016/S0379-7112(00)00003-5

[3] Chien Shen-Wen, and Wu Guan-Yuan, The Strategies of Fire Prevention on Residential Fire in Taipei, Fire Safety Journal, June 2007 doi:10.1016/j.firesaf.2007.04.004

[4] Hui, M.C., F.S.C. Tsui, and M.C. Luo, Fire Incident Characteristics of a Densely Populated Oriental Urban City, 8th international Symposium Proceedings18-23 September, 2005, Beijing, China

[5] Brushlinsky, N., Sokolov, S., The Analysis of Trends and Regularities in the World's Fire Statistics, unpublished paper, 2002.

[6] Sekizawa, Ai, International Comparison Analysis on Fire Risk among the United States, the United Kingdom, and Japan, Proceedings of the Fourth International Symposium on Fire Safety Science, pp. 961-9, 1994, Canada. 